\title{
Vplyv veku na úroveň vybraných koordinačných schopností stolných tenistov
}

\section{Effect of age on the level of selected coordination abilities of table tennis players}

\author{
Henrieta Horníková, Ladislava Doležajová \\ Katedra atletiky, Fakulta telesnej výchovy a športu UK Bratislava
}

\begin{abstract}
Abstrakt
Je dokázané, že reakčný čas sa predlžuje s vekom. Doposial'sa však vel'mi málo autorov zaoberalo časom senzomotorickým, ktorý je obohatený o motorickú zložku. Preto bolo cielom práce preukázat' vekovo závislé zmeny disjunktívnych reakčno-rýchlostných schopností, ktorých výsledkom je senzomotorický čas. Údaje sme získavali vykonaním agility testu prispôsobenému špecifickým potrebám stolného tenisu pomocou prístroja FiTRO Agility check. Testovanými osobami boli stolní tenisti vo veku od 20 do 70 rokov, ktorých sme rozdelili na základe ontogenézy dospelého človeka do 4 vekových kategórií, resp. období. Predpokladali sme, že medzi nimi budú štatisticky významné rozdiely. Taktiež sme predpokladali závislost'senzomotorického času od veku. Jednoduchá ANOVA poukázala na štatisticky významné rozdiely medzi vekovými kategóriami $\left(F_{(2,46)}=10,2 ; p<0,001\right)$. Pearsonov korelačný koeficient poukázal na koreláciu medzi senzomotorickým časom a vekom $(r=0,53 ; p<0,01)$.
\end{abstract}

Klúčové slová: stolný tenis, disjunktívne reakčno-rýchlostné schopnosti, agility test, muži

\begin{abstract}
It is known, reaction time increases with age. Agility time, enriched by a motor component is investigated less. Therefore the aim of this study was to determined age-related differences in disjunctive reaction-speed abilities, where the result is an agility time. Data were obtained by agility test adapted to the specific needs of table tennis using FiTRO Agility check device. Subjects of testing were table tennis players from 20 to 70 years devided into four age categories. We assumed a statistically significant differences between agility time in these categories. We assumed a significant relationship between agility time and age. One-way ANOVA indicated a significant differences in agility time between categories $\left(F_{(2,46)}=10,2 ; p<0,001\right)$. Pearson correlation coefficient indicated significant relationship between agility time and age $(r=0,53 ; p<0,01)$. We found a significant difference between motor reaction to the forehand and backhand side. It was shorter to the forehand in each age category. Our study showed the age-related changes in disjunctive reaction-speed abilities.
\end{abstract}

Key words: table tennis, disjunctive reaction-speed abilities, agility test, men

\section{ÚVOD}

Športový výkon v stolnom tenise je značne ovplyvnený rýchlostnými schopnostami. Ide o rýchlost’ reakčnú a akčnú. Rýchlosṫ reakčná ovplyvňuje mieru agility (schopnost̉ prudko, výbušne a rýchlo akcelerovat', spomalit, zmenit polohu tela a znova čo najrýchlejšie vyštartovat podla Browna \& Ferigna (2005). Rýchlost’ a agilita je spojená so schopnostami silovými, najmä ide o výbušnú silu horných a dolných končatín. Nenahraditel'nú úlohu zohráva aj úroveň koordinačných schopností, najmä čo sa týka osvojovania a zdokonal'ovania technických zručností (Vacenovský, 2014). 
Stolný tenis patrí medzi športy s otvorenými zručnostami a je vhodnejšie používat na zistovanie reakčných schopností agility test, kde je zvýraznená rozhodovacia zložka a anticipácia, ako len rýchlost’ pohybu so zmenou smeru (Tsubouchi et al., 2016; Uchida et al., 2013). Agility test, ktorý postihuje obe zložky, rýchlost' zmeny smeru pohybu aj kognitívnu zložku (rozpoznávanie a anticipácia), sa preto ukazuje byt’ vhodnejší pre tento typ športu ako meranie len času reakčného alebo len rýchlostnej zložky. Prístroj FiTRO Agility check (FiTRONiC, SK) dokáže zachytit senzorickú, rozhodovaciu aj motorickú zložku agility. Práve stolní tenisti dosiahli spomedzi športovcov rôznych špecializácií najkratší čas agility, alebo inak senzomotorický čas (Zemková \& Hamar, 2015).

Normálny proces starnutia je spojený s poklesom niektorých kognitívnych schopností, ako je rýchlost’ spracovania, pamät, jazyk a d’alšie výkonné funkčné schopnosti (Harada et al., 2013). Dykiert et al. (2012) sa vo svojom výskume snažili objasnit a kvantifikovat zmeny v reakčnom čase (jednoduchom aj výberovom) zdravých, starnúcich jedincov. Starí ludia (60+ rokov) dosiahli dlhší reakčný čas v porovnaní s dospelými v strednom (40-59 rokov) a v mladšom dospelom veku (20-39 rokov). Taktiež dodávajú, že väčší rozdiel bol medzi staršími a dospelými v mladšom veku ako medzi starými a dospelými v strednom veku. Tento rozdiel bol výraznejší pri reakcii s výberom ako pri jednoduchej reakcii čo potvrdzuje výraznejší vplyv veku v náročnejších úlohách. Podobné výsledky uvádzajú aj Nikam \& Gadkari (2012), ktorí sledovali vplyv veku, pohlavia na vizuálny aj akustický reakčný čas. Štatistická analýza dát poukázala na to, že vizuálny aj akustický reakčný čas bol signifikantne dlhší u starších (65-75 rokov) ako u mladších (18-20 rokov) probandov. Fakt, že prirodzený spôsob starnutia postupne zvyšuje čas odpovede na podnety, potvrdzujú aj d’alší autori (Luchies et al., 2002).

Podl'a Wolanskeho \& Siniarskej (1974) reakčný čas je najkratší vo veku 22 rokov, potom nasleduje $\mathrm{v}$ dospelosti mierna regresia, ktorá rapídnejšie narastá po 55. roku a reakcia sa d’alej spomaluje vekom. Čeremnych et al. (2006) vo svojej štúdii jasne preukázali priamu závislost’ rýchlosti odpovede na jednoduchý podnet od veku. Namerané hodnoty boli signifikantne horšie u probandov vo veku 75-89 rokov ako u 60-74 a 45-59 ročných probandov. Toto vekovo závislé predlžovanie reakčného času podl'a týchto autorov vzniká v dôsledku spomalenia periférnych senzomotorických procesov.

Štúdiami v oblasti výberovej reakcie sa zaoberali Vaportzis et al. (2013) a Woods et al. (2015) vo svojich experimentoch na probandoch vo vekovom rozpätí 18 až 65 rokov. Výsledkom týchto testovaní bolo, že $\mathrm{v}$ jednoduchšom výberovom reakčnom čase boli starší l'udia signifikantne pomalší ako mladší l’udia Ich výberový reakčný čas sa významne zvyšuje s vekom $(\mathrm{r}=0,47 ; 2,80 \mathrm{~ms} /$ rok), pričom je to spôsobené väčšinou oneskoreným spracovaním motorickej odpovede. Hodnoty nárastu však nie sú celkom totožné, Fozard et al. (1994) uvádzajú 0,5 ms/rok pre jednoduchý a len $1,6 \mathrm{~ms} /$ rok pre disjunktívny reakčný čas. Taktiež bola zistená väčšia variabilita s narastajúcim vekom.

\section{CIEL'}

Ciel’om práce je poukázat na rozdielnu úroveň disjunktívnych reakčno-rýchlostných schopností 20-70ročných stolných tenistov z hl’adiska ontogenézy človeka. 


\section{HYPOTÉZY PRÁCE}

H1 Predpokladáme, že existujú štatisticky významné rozdiely v senzomotorickom čase medzi vekovými kategóriami.

H2 Predpokladáme, že existuje štatisticky významný vztah medzi senzomotorickým časom a vekom.

\section{METODIKA}

Súbor pozostával z aktívnych stolných tenistov absolvujúcich 2 až 3 tréningy a 1 zápasové stretnutie týždenne, vo veku 20 až 70 rokov. Takmer polovica probandov sa venuje rekreačne (1× do týždňa) aj inému športu, najčastejšie futbalu a tenisu. V kategóriách nad 30 rokov sa 11 probandov liečilo na vysoký krvný tlak a 2 probandi na cukrovku.

Na základe dostupnej literatúry Vágnerová (2007) sme ich rozdelili podl’a ontogenézy človeka na 4 vekové kategórie (tab. 1).

Testované osoby sme vyberali zámerne, čím sme chceli zabránit vel'kým výkonnostným rozdielom týchto hráčov. Všetci probandi sa nachádzali na úrovni 3. až 5. ligy z rôznych krajov Slovenska.

Tab. 1: Charakteristika veku, telesného rozvoja, indexu telesnej hmotnosti a veku špecializácie jednotlivých vekových kategórií (priemer \pm smerodajná odchýlka)

\begin{tabular}{|l|c|c|c|c|c|c|}
\hline $\begin{array}{l}\text { Veková } \\
\text { kategória }\end{array}$ & $\begin{array}{c}\text { Počet } \\
\text { probandov }\end{array}$ & $\begin{array}{c}\text { Decimálny } \\
\text { vek }\end{array}$ & $\begin{array}{c}\text { Telesná vóška } \\
{[\mathbf{c m}]}\end{array}$ & $\begin{array}{c}\text { Telesná hmotnost' } \\
{[\mathbf{k g}]}\end{array}$ & BMI & $\begin{array}{c}\text { Dížka športovej } \\
\text { špecializácie (roky) }\end{array}$ \\
\hline 20-29 rokov & 10 & $26,2 \pm 2,7$ & $184,7 \pm 9,0$ & $79,2 \pm 11,7$ & $23,2 \pm 2,9$ & $9,1 \pm 3,9$ \\
\hline $30-44$ rokov & 19 & $38,3 \pm 5,0$ & $179,9 \pm 5,7$ & $89,6 \pm 15,4$ & $27,6 \pm 4,1$ & $14,7 \pm 9,5$ \\
\hline $45-59$ rokov & 12 & $52,2 \pm 3,5$ & $174,4 \pm 4,4$ & $89,3 \pm 13,3$ & $29,4 \pm 4,7$ & $18,6 \pm 13,0$ \\
\hline $60-70$ rokov & 9 & $62,7 \pm 2,0$ & $173,9 \pm 3,5$ & $87,3 \pm 13,4$ & $29,0 \pm 5,0$ & $20,7 \pm 13,7$ \\
\hline
\end{tabular}

\section{METÓDY SPRACOVANIA A VYHODNOTENIA ZÍSKANÝCH ÚDAJOV}

Testovanie prebiehalo od decembra 2016 do decembra 2017, ked'že sa nedalo k takému množstvu hráčov dostat naraz.

Najprv sme hráčom odmerali telesné ukazovatele podla Sedláček \& Cihová (2009) a zaznamenali sme si aj ich dátum narodenia a dížku športovej špecializácie stolný tenis. Okrem údajov v tab.1 sme zistovali aj požívanie farmakologických prostriedkov a aj iné aktivity, ktoré vykonávali aspoň $1 \times$ do týždňa mimo stolného tenisu. Zistené skutočnosti nám mohli pomôct’ pri interpretovaní výsledkov našej práce, ked’že sú to jedny z mnohých faktorov, ktoré majú vplyv na disjunktívne reakčno-rýchlostné schopnosti.

Samotný test sa vykonával vždy v športovej hale vo večerných hodinách pred tréningom alebo zápasom (cca o 18:00 hod.),

Testovali sme pomocou vlastného testu, ktorý sme si vytvorili vychádzajúc zo špecifických podmienok stolného tenisu. Využili sme pri tom prístroj FiTRO Agility check (FiTRONIC s.r.o., Bratislava, Slovenská republika) s dvomi kontaktnými platňami, ktoré boli pomocou interfejsu napojené na počítač.

Probandi zaujali strehový postoj (ruka v strede stola) vo vzdialenosti $50 \mathrm{~cm}$ od koncovej hrany. Platne boli umiestnené v rohoch stola na realizáciu forhendovej a bekhendovej reakcie. Š́rka stola bola štandardných $1,525 \mathrm{~m}$. Úlohou testovanej osoby bolo vykročit a dotknút sa jednej 
z platní podl'a zobrazeného stimulu na obrazovke (žltý kruh na modrom pozadí) a vrátit sa spät do štartovej pozície. Dotyk sa vykonával vždy hracou rukou do oboch strán na postihnutie reakcie do forehandu resp. do backhandu. Test pozostával z 32 vizuálnych stimulov (16 do každého smeru) s náhodným generovaním lokalizácie a s časom generovania podnetov v rozpätí od 200 do $500 \mathrm{~ms}$.

Výsledok testu je priemer najlepších reakcií ( 8 do každého smeru) v lepšom z dvoch pokusov.

Pri analýze dát bol použitý štatistický program Statistica 12 Trial (TIBCO Software Inc., Palo Alto, CA, USA).

Využité štatistické metódy:

- základné štatistické charakteristiky (aritmetický priemer, smerodajná odchýlka, medián, variačné rozpätie)

- Kolmogorov-Smirnov test pre zistovanie normality rozdelenia početnosti

- Levenov test pre rovnost variácií

- jednoduchá (one-way) ANOVA pre zistovanie štatisticky významných rozdielov medzi vekovými kategóriami a Tukey-ho (HSD) test pre zistovanie rozdielov medzi jednotlivými vekovými kategóriami

- Pearsonov korelačný koeficient (r) pre zistovanie vztahu medzi dvoma premennými a koeficient determinácie $\left(\mathrm{r}^{2}\right)$,

- zvolená hladina štatistickej významnosti: $\alpha=0,05$

\section{VÝSLEDKY}

Jednoduchá analýza rozptylu (one-way ANOVA) poukázala na štatisticky významné rozdiely medzi vekovými kategóriami $\left(\mathrm{F}_{(2,46)}=10,2 ; \mathrm{p}<0,001\right)$. Preto konštatujeme potvrdenie H1. Tukey-ho test, ktorý nám hovorí o tom, medzi ktorými konkrétnymi kategóriami sa rozdiely nachádzajú, môžeme vidieț v tab. 2.

Tab. 2: Rozdiely v senzomotorickom čase medzi vekovými kategóriami (aritmetický priemer \pm smerodajná odchýlka; $\mathrm{p}$ - hodnota)

\begin{tabular}{|c|c|c|c|c|}
\hline \multirow{2}{*}{ Veková kategória } & \multirow{2}{*}{ Senzomotorický čas $[\mathbf{m s}]$} & \multicolumn{3}{|c|}{ Veková kategória } \\
\cline { 3 - 5 } & & $\mathbf{2 0 - 2 9}$ & $\mathbf{3 0 - 4 4}$ & $\mathbf{4 5 - 5 9}$ \\
\hline $20-29$ & $437,0 \pm 29,2$ & - & - & - \\
\hline $30-44$ & $435,2 \pm 35,9$ & 0,99 & - & - \\
\hline $45-59$ & $477,0 \pm 37,6$ & 0,04 & 0,009 & 0,39 \\
\hline $60-70$ & $501,2 \pm 21,8$ & 0,001 & $<0,001$ & - \\
\hline
\end{tabular}

Významný rozdiel v senzomotorickom čase môžeme sledovat medzi 2. a 3. vekovou kategóriou. Tento rozdiel v rýchlosti motorickej reakcie je 8,8 \% (41,8 ms). Medzi prvou a druhou kategóriou nie je štatisticky významný rozdiel, to isté platí aj medzi tretou a štvrtou kategóriou. Dokonca stolní tenisti vo veku 30-44 rokov dosiahli o 2,2 ms kratší senzomotorický čas v porovnaní s 20-29ročnými hráčmi, čo predstavuje $0,4 \%$. Pearsonov korelačný koeficient preukázal vzájomný vzṫah medzi senzomotorickým časom a vekom stolných tenistov $(\mathrm{r}=0,53 ; \mathrm{p}<0,01)$. Koeficient determinácie $\mathrm{r}^{2}=0,28$ (28 \%), znamená, že výsledný senzomotorický čas je vo výraznej tesnosti s vekom.

Vychádzajúc z výsledkov konštatujeme, že H2 sa nám potvrdila. Preukázali sme závislost’ senzomotorického času od veku. 


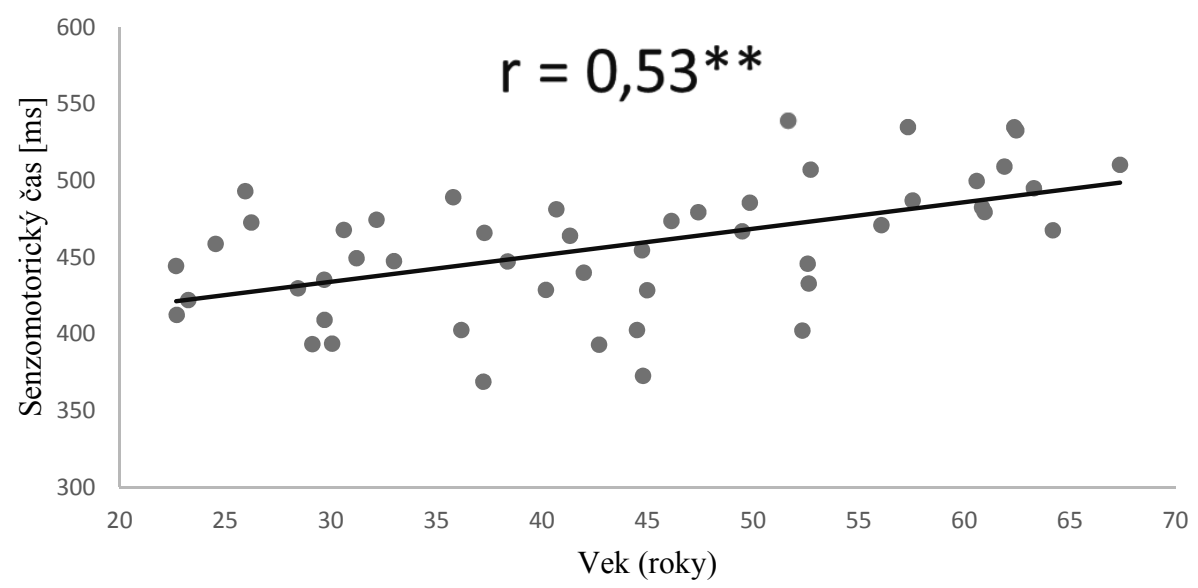

Obr. 1: Závislost' senzomotorického času od veku

\section{DISKUSIA}

Výsledky poukázali na štatisticky významné rozdiely medzi 2. a 3. vekovou kategóriou stolných tenistov. Medzi ostatnými sledovanými kategóriami sme nezaznamenali signifikantné rozdiely. Obdobie po 45. roku života je podl’a Gregora (2014) medzníkom, kedy sa znižuje celková výkonnost'. Výrazné predlžovanie reakčného času nastáva v období po 50-tke (John et al., 2016), tým sa dá vysvetlit vel'ký spád aj v senzomotorickom čase našich stolných tenistov. Štatisticky nevýznamné rozdiely medzi 1. a 2. vekovou kategóriou môžeme pripísat tomu, že najlepšia výkonnost' sa dosahuje vo veku približne 26 rokov, obdobie od 31 do 45 rokov sa považuje za obdobie stabilizácie a vyvrcholenia psychickej a fyzickej kondície (Gregor, 2014). Úlohu tu mohla zohrat aj dížka športovej špecializácie, ktorá podl’a Vidja et al. (2012) má vplyv na úroveň reakčných schopností a hráči 2. kategórie majú dížka športovej špecializácie vyšší o viac ako 5 rokov. Preto ich výkon mohol byt nepatrne lepší v porovnaní s mladšou kategóriou. Treba ešte spomenút, že 3 najlepšie priemerné senzomotorické časy boli namerané v 2. kategórii (30-44 rokov). Ked’že najvýraznejší pokles v úrovni reakčných schopností nastáva okolo 50-teho roku života, nemožno očakávat, že v neskoršom veku bude ešte výraznejší. Tým si vysvetlujeme aj nevýznamný rozdiel medzi 45- až 59ročnými a hráčmi po 60-tke. Preto aj predíženie senzomotorického času nastáva (o 4,8 \%), ale nie je už také markantné ako to bolo medzi predchádzajúcimi dvoma kategóriami. Jednou z d'alších príčin môže byt nižšia hodnota BMI v najstaršej kategórii v porovnaní s predchádzajúcou $(29,0 \pm 5,0$, resp. 29,4 $\pm 4,7)$.

Podarilo sa nám preukázat aj štatisticky významný vztah medzi senzomotorickým časom a vekom. Podobné výsledky potvrdzujú aj Woods et al. (2015) v oblasti výberovej reakcie, čiže bez motorickej zložky. Korelácia dosiahla hodnotu r $=0,47$, ktorá bola taktiež významná na $1 \%$ hladine štatistickej významnosti. Podla Der \& Deary (2006) sa výberový reakčný čas taktiež predlžuje počas celého obdobia dospelosti.

Viacero autorov sa zaoberá agility testami zachytávajúcimi len motorickú zložku bez možnosti rozhodovania sa a rýchlosti reakcie (Kotyal, 2017; Singh et al., 2017). Testované osoby sú väčšinou len deti a adolescenti do 18 rokov. V období po 40-tke dochádza k poklesu rýchlych svalových vláken a k zníženiu rýchlosti svalovej kontrakcie (Faulkner et al., 2008). Ked’že náš test zahŕňa na rozdiel od iných aj rýchlost' motorickej odpovede, závislost' senzomotorického času od veku je oprávnene o čosi vyššia ako závislost’ reakčného času od veku. O postupnej zmene však napo- 
vedá aj najnovšia štúdia Sobolewski et al. (2017), ktorí uvádzajú významné rozdiely v rýchlosti rozhodovania medzi mladými mužmi ( $24 \pm 2$ roky) a mužmi v strednom ( $50 \pm 2$ roky) a staršom veku $(66 \pm 4$ roky) $(\mathrm{p}=0,027)$. Taktiež celkový čas pozostávajúci z rozhodovacej a motorickej zložky, čo je vlastne reaktívna agilita, bol významne kratší v najmladšej kategórii v porovnaní so staršími $(\mathrm{p}<0,001)$.

O reaktívnej agilite $\mathrm{v}$ raketových športoch je doposial' $\mathrm{v}$ odbornej literatúre omnoho menej vedeckých výskumov ako o jednoduchej resp. výberovej reakcii. Táto reaktívna agilita v stolnom tenise je založená na prílete loptičky k súperovi a následnom zahájení úderu súpera (Gillet et al., 2010). Do načasovania pohybu je z časti zapojená aj anticipácia. Rozsah jej zapojenia závisí od schopnosti športovca vnímat’ a interpretovat predčasné náznaky z pohybového správania sa súpera (Holmberg, 2015).

Na tomto základe a vlastných predchádzajúcich skúseností z testovania stolných tenistov v juniorskom veku sme modifikovali test podl'a Vacenovského. Realizovali sme testovanie na vzorke aktívne hrajúcich stolných tenistov vo vekovom rozpätí 20-70 rokov.

Pripúšţame aj isté výkonnostné rozdiely medzi nimi, ktorých vplyv sme sa však snažili eliminovat výberom hráčov len z 3. až 5. ligy. Hoci sme zistovali požívanie farmakologických prostriedkov, nedokážeme presne preukázat ich možný vplyv na výkon v teste. Takýchto probandov však bolo málo a okrem prvej kategórie boli rozdelení rovnomerne, čiže nespadali všetci do jednej. Preto ak aj tieto farmakologické prostriedky ovplyvnili nejakým spôsobom ich výkon v teste, určite to nebolo z nášho pohl'adu rozhodujúce. Výskumy autorov, ktorí sledovali vplyv farmakologických prostriedkov na jednoduchý alebo výberový reakčný čas nie sú jednoznačné (Jäkälä et al., 1999; Rooy et al., 1985; Sidhu et al., 2015).

Pripúštame, že i biorytmické zmeny, vplyv počasia alebo únavy pri testovaní môžu individuálne vplývat na úroveň reakčných schopností. Z týchto dôvodov sme sa im snažili vyhnút aspoň pomerne jednotným časom testovania všetkých probandov.

Diskutabilná zostáva aj východisková vzdialenost použitá v našom teste agility, ktorá bola $50 \mathrm{~cm}$. Pre výraznejšie zachytenie motorickej zložky by bola dlhšia vzdialenost pravdepodobne vhodnejšia, avšak pre probandov vo vyšších vekových kategóriách by v tom prípade mohol byt celkový počet stimulov už vyčerpávajúci. Preto nám pol metra prišlo ako vhodný kompromis.

V budúcnosti bude asi nevyhnutné realizovat testovanie na objektívnejších a modernejších prístrojoch, aby sme prispôsobili podmienky testovania pre všetkých probandov z pohladu ich telesných ukazovatel’ov, predovšetkým telesnej výšky.

\section{ZÁVERY}

Podarilo sa nám preukázat, že existujú štatisticky významné rozdiely medzi vekovými kategóriami stolných tenistov. H1 sa potvrdila. Významný rozdiel bol medzi stredným a starším obdobím dospelosti. Rozdiely sme nepreukázali medzi obdobiami mladšej a strednej dospelosti rovnako ako medzi staršou dospelostou a starobou. Preto môžeme konštatovat, že najvýraznejšie predlžovanie senzomotorického času nastáva v období po 45-ke, ktoré v neskoršom veku už nie je také markantné.

Preukázali sme aj vzájomnú závislost̉ senzomotorického času od veku. H2 sa nám taktiež potvrdila. $\mathrm{V}$ podstate, s narastajúcim vekom nám úroveň týchto schopností postupne klesá. Podobnú závislost potvrdzujú aj iní autori medzi výberovým reakčným časom a vekom. $V$ ich testoch však nie je zachytená motorická zložka, čím sa líšia od toho nášho. Z fyziologického hl'adiska dochádza vplyvom veku k zníženiu rýchlych svalových vláken, ktoré sú pre rýchlosṫ motorickej odpovede dôležité. Preto môžeme usúdit, že závislost’ senzomotorického času od veku je oprávnene o čosi vyššia ako závislost reakčného času od veku. 


\section{Reference}

BROWN, L. E. \& FERRIGNO, V. A. (2005). Training for speed, agility, and quickness. Champaign, IL: Human Kinetics.

ČEREMNYCH, E., ALEKNA, V., JUOZULYNAS, A., \& GAIGALIENÉ, B. (2006). Time of response to different simple stimuli in 45-90-year-old persons. Biologija, Lietuvos mokslu akademija 4, pp. 60-64. Dostupné z: https://epublications.vu.lt/ object/elaba:6172394/

DER, G. I. \& DEARY, J. (2006). Age and sex differences in reaction time in adulthood: results from United Kingdom Health and lifestyle Survey. Psychology and Aging March 21(1), 62-73. Dostupné z: https://www.ncbi.nlm.nih.gov/pubmed/16594792

DYKIERT, D., DER, G., STARR, J. M. \& DEARY, I. J. (2012). Age differences in intra-individual variability in simple and choice reaction time: Systematic review and meta-analysis. PLoS One 7(10) (45759) Dostupné z: http://journals.plos.org/ plosone/article?id=10.1371/journal.pone.0045759

FAULKNER, J. A., DAVIS, C. S., MENDIAS, CH. L. \& BROOKS, S. V. (2008). The aging of elite male athletes: age-related changes in performance and skeletal muscle structure and function. Clinical Journal of Sports Medicine, 18(6), pp. 501-507. Dostupné z: https://www.ncbi.nlm.nih.gov/pmc/articles/PMC3928819/

FOZARD, J. L., VERCRUYSSEN, M., REYNOLDS, S. L., HANCOCK, P. A. \& QUILTER, R. E. (1994). Age differences and changes in reaction time: The Baltimore longitudinal study of aging. Journal of Gerontology, 49(4), pp. 179-189. Dostupné z: https://doi.org/10.1093/geronj/49.4.P179

GILLET, E., LEROY, D., THOUVARECQ, R., MÉGROT, F., \& STEIN, J. (2010). Movement-Production Strategy in Tennis: a Case Study. Journal of Strength and Conditioning Research. 24(7), pp. 1942-1947. Dostupné z: https://www.researchgate. net/publication/44680101_Movement-Production_Strategy_in_Tennis_a_Case_Study

GREGOR, T. (2014). Základy všeobecnej a vývinovej psychológie. Bratislava: Mauro Slovakia s.r.o.

HARADA, C. N., NATELSON LOVE, M. C., \& TRIEBEL, K. L. (2013). Normal cognitive aging. Clinics in Geriatric Medicine, 29(4), s. 737-752. Dostupné z: https://www.ncbi.nlm.nih.gov/pmc/articles/PMC4015335/

JÄKÄLÄ, P., RIEKKINEN, M., SIRVIÖ, J., KOIVISTO, E. \& RIEKKINEN, P. (1999). Clonidine, but not guanfacine, impairs choice reaction time performance in young healthy volunteers. Neuropsychopharmacology 21, pp. 495-502. Dostupné z: http://www.nature.com/npp/journal/v21/n4/full/1395372a.html

HOLMBERG, P. (2015). Agility training for experienced athletes: A dynamical system approach. Strength and Conditioning Journal 37(3), pp. 93-98. Dostupné z: https://www.researchgate.net/publication/282552160_Agility_Training_for_ Experienced_Athletes

JOHN, N. A., SARANYA, K., DHANALAKSHMI, Y., \& JOHN, J. (2016). Aging-mediated neuromuscular instability and delayed choice reaction time. International Journal of Medical Science and Public Health 5(11), pp. 2269-2273. Dostupné z: http:// www.ejmanager.com/mnstemps/67/67-1461137579.pdf

KOTYAL, S. S. (2017). Comparison of agility volleyball and basketball players. International Journal of Physical Education, Sports and Health, 4(1), pp. 269-270. Dostupné z: https://pdfs.semanticscholar.org/7fb1/fcd8c83c3327bf4f09736eba0c8a2a9f5477.pdf

LUCHIES, C. W., SCHIFFMAN, J., RICHARDS, L. G., THOMPSON, M. R., BAZUIN, D., \& DEYOUNG, A. J. (2002). Effect of age, step direction and reaction condition on the ability to step quickly. The Journals of Gerontology, Series A 57(4), pp. $246-249$. Dostupné z: https://doi.org/10.1093/gerona/57.4.M246

NIKAM, L. H. \& GADKARI, J. V. (2012). Effect of age, gender and body mass index on visual and auditory reaction times in indian population. Indian Journal of Physiology and Pharmacology, 56(1), pp. 94-99. Dostupné z: https://pdfs.semanticscholar.org/aebf/6d2f1453b7c5931ef287c1ee07223f3a9661.pdf

ROOY, P., MYBURGH, D. P. \&. CILIERS, J. (1985). Evaluation of the effect of atenolol on reaction time of healthy volunteers. European Journal of Clinical Pharmacology (Suppl. 1), pp. 105-107. Dostupné z: https://link.springer.com/ article/10.1007/BF00543721

SEDLÁČEK, J. \& CIHOVÁ, I. (2009). Športová metrológia. Bratislava: ICM Agency.

SIDHU, J., MITTU, S., \& SIDHU, H. (2015). Comparative study of reaction time in type 2 diabetics and non-diabetics. Scholars Journal of Applied Medical Sciences 3(1G),pp. 527-529. Dostupné z: http://saspublisher.com/wp-content/ uploads/2015/01/SJAMS-31G527-529.pdf

SINGH, S., VARSHA, H. S., SINGH A., \& SINGH, K. (2017). A comparative study of selected motor fitness components among badminton table tennis and squash. International Journal of Physical Education, Sports and Health, 4(3), pp. 203-206. Dostupné z: http://www.kheljournal.com/archives/2017/vol4issue3/PartD/4-3-57-883.pdf

SOBOLEWSKI, E. J., THOMPSON, B. J., CONCHOLA, E. C., \& RYAN, E. D. (2017). Development and examination of a functional reactive agility test for older adults. Aging Clinical and Experimental Research. (ahead of print). Dostupné z: https:// www.ncbi.nlm.nih.gov/pubmed/28608256

TSUBOUCHI, S., DEMURA, S., UCHIDA, Y., MATSUURA, Y., \& UCHIDA, H. (2016). Agility characteristics of various athletes based on a successive choice-reaction time. American Journal of Sports Science and Medicine, 4(4), pp. 98-102. Dostupné z: http://www.sciepub.com/ajssm/content/4/4?v=3

UCHIDA, Y., DEMURA, S., NAGAYAMA, R. \& KITABAYASHI, T. (2013). Stimulus tempos and the reliability of the successive choice-reaction time test. Journal of Strength and Conditioning Research, 27(3), pp. 848-853. Dostupné z: https://journals. Iww.com/nsca-jscr/Fulltext/2013/03000/Stimulus_Tempos_and_the_Reliability_of_the.38.aspx

VACENOVSKÝ, P. (2014). Struktura sportovního tréninku u stolního tenisu. In P. Korvas \& L. Bedřich, Struktura sportovního výkonu: učební texty pro studenty FSpS. Brno: Masarykova univerzita. 
VÁGNEROVÁ, M. (2007). Vývojová psychologie ll., dospělost a stáří. Praha: Karolinum. VAPORTZIS, E., GEORGIOU-KARISTIANIS, N., \& STOUT, J. C. (2013). Dual task performance in normal aging: A comparison of choice reaction time tasks. PloS One, 8(3), pp. 60265. Dostupné z: http://journals.plos.org/plosone/article?id=10.1371/journal.pone.0060265

VIDJA, K., DODHIA, S. S., BHABHOR, M. K., BHANDERI, P., CHUDASAMA, J., \& JANI, H. (2012). Long term playing of table tennis improve the visual reaction time. In: International Journal of Scientific Research [online]. November 2012, 1(6), pp. 155-156. Dostupné z: https://www.researchgate.net/publication/314862544_Long_Term_Playing_of_Table_ Tennis_Improve_the_Visual_Reaction_Time

WOLANSKI, N. \& SINIARSKA, V. (1974). Studies on development of motorics in polish populations. Ontogeneze lidské motoriky: soubor referátů z V. semináře antropomotoriky konaného ve dnech 29.-31. 5. 1985 v Olomouci. Praha: Olympia.

WOODS, D. L., WYMA, J. M., YUND, E. W., HERRON, T. J. \& REED, B. (2015). Age-related slowing of response selection and production in a visual choice reaction time tasks. Frontiers in Human Neuroscience, 9(193). Dostupné z: http://journal. frontiersin.org/article/10.3389/fnhum.2015.00193/full

ZEMKOVÁ, E., \& HAMAR, D. (2015). Toward and Understanding of Agility Performance $-2^{\text {nd }}$ edition. Boskovice: František Šalé - Albert.

\section{Corresponding author:}

Adresa mailová: dolezajova@fsport.uniba.sk

Katedra atletika, FTVŠ UK Bratislava 